\title{
STRATEGIES FOR INCREASING AWARENESS ON ENVIRONMENTAL SANITATION IN MAINTENANCE KNOWLEDGE SOCIETY ENVIRONMENT IN MAKASSAR
}

\author{
Ronny, Gufran Darma Dirawan, Muhammad Ardi, Bakhrani Rauf
}

\begin{abstract}
This study aims to determine differences of knowledge society before and after being given counseling using audio-visual media and media images. This study was conducted in Makassar, South Sulawesi Province with the type of quantitative research experiments in One-group pretestposttest design. The population in this study is the whole community that is in the red zone of the District Tallo Makassar. The results shows that there is an extension by using audio-visual media is $\mathrm{t}_{\text {count }}$ is equal to $3,436>\mathrm{t}_{{ }_{\text {table }}}$ value of $(0: 05 ; 24)$ was 1,711 with sig $0.002<0.05$. Because $t$ count $>\mathrm{t}$-table and sig $<0.05$ then it can be concluded that there are significant differences between the level of public knowledge before and after counseling sanitation by using audio-visual media. Extension by using the media image is $\mathrm{t}_{\text {count }}$ value is equal to $3,055>\mathrm{t} \mathrm{t}_{\text {table }}$ value of $(0: 05 ; 24)$ was 1,711 with sig $0.005<0.05$. Because t- ${ }_{\text {count }}>\mathrm{t}^{-}{ }_{\text {table }}$ and sig $<0.05$ then it can be concluded that there are significant differences between the level of public knowledge before and after counseling sanitation by using media images.
\end{abstract}

Keywords: Knowledge, Environmental Sanitation

\section{Introduction}

Law No. 23, 1992 about the health article 22, stated that the environmental health organized to realize the quality of a healthy environment. Environmental health carried out against community livelihoods, neighborhoods, work environment, public transport, it also support by environments. Law of the Republic of Indonesia number 36, year 2009 on health contained in the articles that govern the Environmental Health Efforts aimed to establish the quality of a healthy environment, whether physical, chemical, biological, and social that allows every person to achieve the degree of health is the highest.

To achieve these objectives the government is earnestly and continuously strive to improve the quality and coverage of health services. To raise awareness of the willingness and ability of healthy life for everyone in order to improve an optimal degree of public health it is based on the Regulation of the Ministry of Health of the Republic of Indonesia Number 416/Menkes/Per/IX/1990, that the clean water used must meet the requirements of water quality and drinking water must meet the requirements of quality in accordance with the Regulation of the Ministry of Health of the Republic of Indonesia No.492/Menkes/Per/IV/2010.

Based on the results on preliminary observations that has been conducted on 21 until January 22, 2014 it can be describe the condition of sanitation (wells) in

Address for communication: Ronny, Gufran Darma Dirawan, Muhammad Ardi, Bakhrani Rauf, Post Graduate Program, Makassar State University, E-mail: ronny_muntu@yahoo.co.id, and gufrandarma@yahoo.com 
District Tallo Makassar was incompatible with the expectations, both in terms of the construction of sanitary conditions is still very poor and did not meet the requirements of environmental health. Therefore it was have high risk, due to the environmental pollution to water quality physical (turbid water), both derived from family toilets, garbage and household waste water. In preliminary observations, the researcher also supported by the profile of Makassar City Health Department in 2013 about the environmental conditions in the District Tallo Makassar which states that the condition of the area included in the list of the red zone and this area is very troubling in two village communities, namely in the Rappokalling Village and Kalukubodoa Village Tallo sub-district Makassar. Rauf (2000) concluded that there is a change in attitude towards the positive environmental care in the community, after on they scouted about considerable environmental knowledge.

One of the goals of Global commitment Millennium Development Goals (MDGs), (2015) to be achieved is to ensure the repair/reconstruction of environmental conditions with one target is to reduce by half the proportion of Indonesian people who do not have access to drinking water and basic sanitation for consumption, the goal is in line with the strategy of the Ministry of health plans that increase community empowerment, private sector and civil society in health development through national and global cooperation.

Based on WHO-UNICEF report Joint Monitoring Program; the performance of the Water and Sanitation sector in Indonesia (1990), that the earth is a natural resource that is infinite, life will be more meaningful if we have wealth, created to conquer nature, science and new technology will resolve the environmental problems, the human being above human nature that is separate from nature and are superior, and the waste is expected in every human existence.

One of the strategies for achieving health improvement, productivity and quality of life, is through the Program of Water Supply and Sanitation Community Based (PAMSIMAS) (2002). Evaluation of the implementation of these activities have not been encouraging appropriate education goals based cognitive domain and affective domain in Taxonomy Benjamin Bloom (1956); in Dimyati and Mudjiono (1994).

Notoatmodjo (2003), environmental health is essentially a condition or state of optimum environment so that the positive effect on the realization of optimum health status as well. While Anwar, (1990) Sanitation is a public health effort that focuses on the supervision of the various environmental factors that affect or may affect the degree of human health. Sumantri (2010), suggested that the science of environmental sanitation is part of environmental health sciences and business, including how individuals or communities to control and to control the external environment that are harmful to health and which could threaten human survival.

According Notoatmojo (2007) Environmental sanitation is the health status of an environment that includes a housing, sewerage, water supply and so on. Hurlock 
(1998), cited by Nursalam (2001), getting sufficient age and maturity level of a person's strength will be more mature in thinking and working.

Based on the description set forth previously, the researchers are interested in doing research with the title "Environmental Sanitation Extension Strategy Against Increasing Knowledge and Public Attitudes in Maintaining Environment In Makassar"

\section{Research Method}

This research is a quantitative experiments with form One-group pretest-posttest design. The population in this study is the whole community that is in the red zone of the District Tallo Makassar. While the sample selected by purposive random sampling (criteria) on the districts, the districts Tallo which consists of several villages, then the sample is set at two villages namely Rappokalling villages and villages Kaluku Bodoa, which consists of 25 people in the Rappokalling village and 25 people in Kaluku Bodoa village. So that the amount of sample amounted to 50. Data were collected using the instrument in the form of a pretest of knowledge about sanitation management then given intervention or treatment with counseling activities related to the improvement of water quality by means of a simple water filtration using audio-visual media outreach and media images. After interventions completed then carried back the final measurement (post test). Data analysis technique using descriptive analysis and inferential statistical analysis.

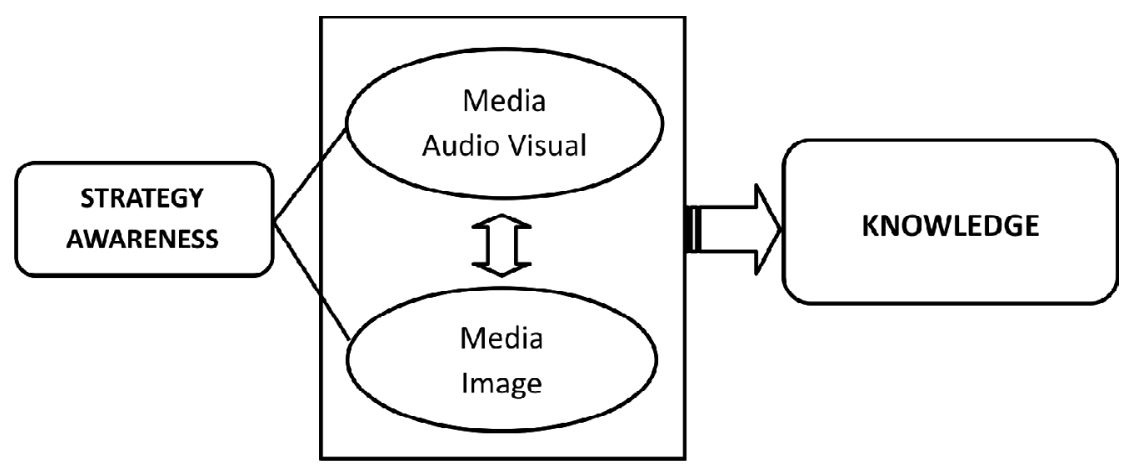

Figure 1: Design Research

The experiment model can be describ below:

TABLE 1: THE EXPERIMENT MODEL

\begin{tabular}{llclc}
\hline & & $B_{1}$ Media Visual & & B Media Image \\
\hline Knowledge of sanitation & $\mathrm{A}_{1}$ High & $\mathrm{A}_{1} \mathrm{~B}_{1}$ & $\mathrm{~A}_{1} \mathrm{~B}_{2}$ \\
\cline { 2 - 5 } & $\mathrm{A}_{2}$ Low & $\mathrm{A}_{2} \mathrm{~B}_{1}$ & $\mathrm{~A}_{2} \mathrm{~B}_{2}$ \\
\hline
\end{tabular}




\section{Research Results}

\section{Descriptive Analysis}

Based on the results of the field survey the data shows that:

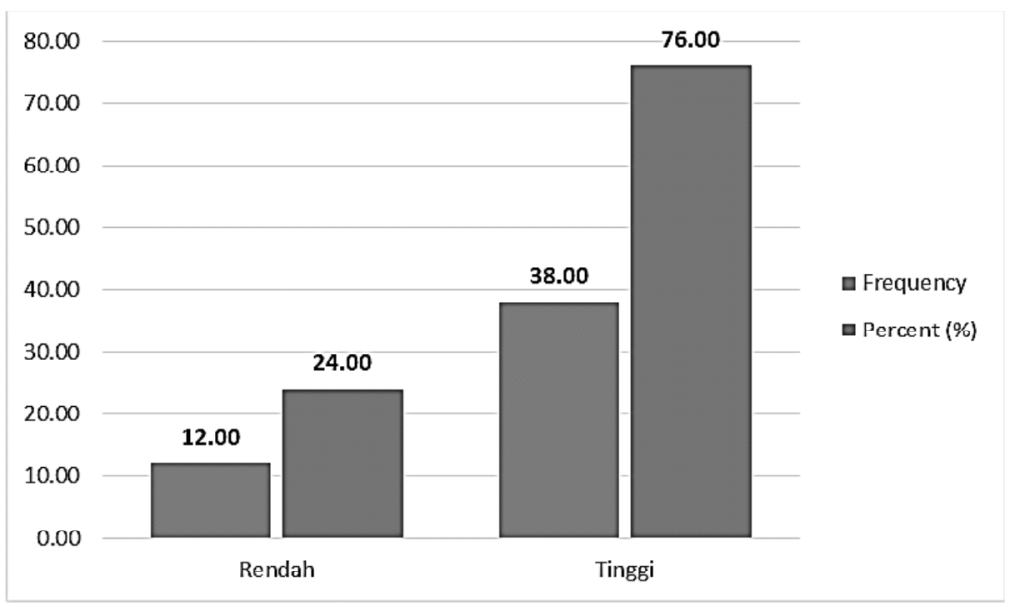

Figure 2: Distribution chart levels of public knowledge prior to the extension of sanitation

Figure 2 above shows a comparison between the level of public knowledge, the data collected by questionnaire instrument. Category low level of knowledge acquired percentage of $24.00 \%$ with a frequency of 12 respondents from a total of 50 respondents. Categories high level of knowledge acquired percentage of $76.00 \%$ with a frequency of 38 respondents from a total of 50 respondents. Data such indicates that respondents to the level of public knowledge prior to intervention in the form at the high category.

Furthermore, the results of descriptive analysis using SPSS 20 program to describe the level of public knowledge in the form of post-test knowledge of sanitation management after the intervention in the form of counseling related to the improvement of water quality by means of a simple water filtration can be seen in the table below:

Therefore we have see from the graph there is a significant differences between the pattern knowledge before and after the experiment of audio visual and visual image model of conseling in the community.

Figure 3 above shows a comparison between the level of public knowledge, the data collected by the instrument pretest questionnaire form of knowledge about sanitation management after the intervention in the form of counseling related to the improvement of water quality by means of a simple water filtration. Category low level of knowledge acquired percentage of $22.00 \%$ with frequency 11 


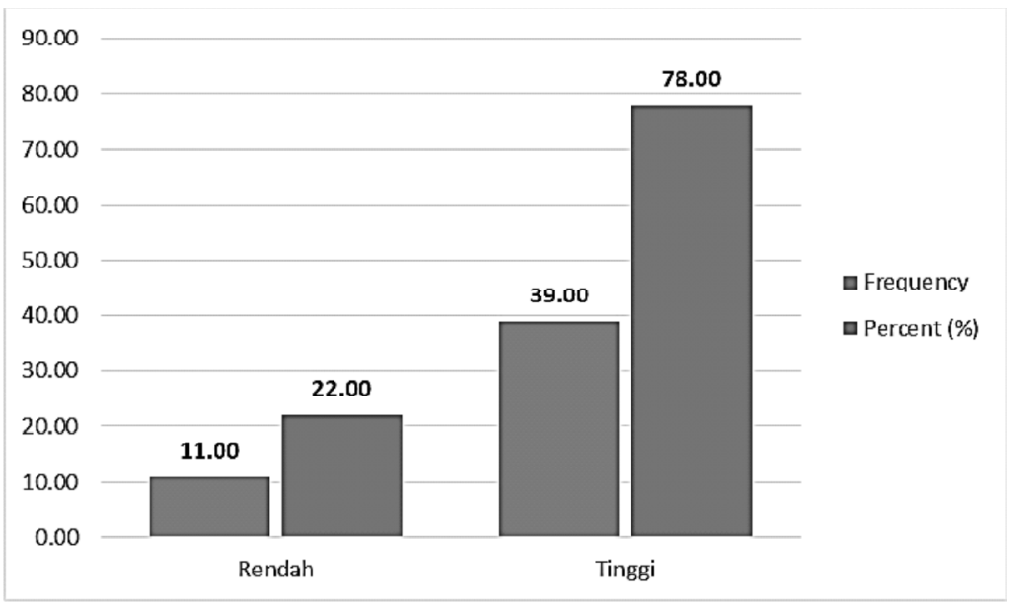

Figure 3: Distribution chart level of public knowledge after counseling sanitation

respondents from a total of 50 respondents. Categories high level of knowledge acquired percentage of $78.00 \%$ with a frequency of 39 respondents from a total of 50 respondents. The majority of respondents to the level of public knowledge after the intervention in the form of counseling related to the improvement of water quality by means of a simple water filtration with high category.

\section{Infrensial Analysis}

Paired t-test is usually examine the differences between the two observations. Paired $t$ test was usually done on the subject tested on the situation before and after the process, or in pairs or a similar subject. Paired t-test results for the knowledge of the management of sanitation before and after the intervention in the form of counseling related to the improvement of water quality by means of a simple water filtration using audio-visual media can be seen in the table below:

TABLE 2: PAIRED SAMPLES STATISTICS COMMUNITY KNOWLEDGE BEFORE AND AFTER COUNSELING SANITATION WITH AUDIO-VISUAL MEDIA

\begin{tabular}{llrrrr}
\hline & Mean & $N$ & Std. Deviation & Std. Error Mean \\
\hline Pair 1 & Before & 6.8000 & 25 & 1.29099 & .25820 \\
& After & 7.8400 & 25 & 1.34412 & .26882 \\
\hline
\end{tabular}

Source: Data Processing, 2015

Table above shows that the mean and std. deviation of public knowledge before and after counseling. Before the extension by using audio-visual media the mean level of knowledge of 25 samples obtained 6.8000 with std. deviation 1.29099. while after counseling by using audio-visual media number knowledge level mean is equal to 7.8400 with std. deviation 1.34412 . 
TABLE 3: PAIRED SAMPLES CORRELATIONS PUBLIC KNOWLEDGE BEFORE AND AFTER COUNSELING SANITATION WITH AUDIO-VISUAL MEDIA

\begin{tabular}{rrrrr}
\hline & $N$ & Correlation & Sig. \\
\hline Pair 1 & Before and After & 25 & .741 & .009 \\
\hline
\end{tabular}

Source: Data Processing, 2015

The test results showed that the correlation between the two variables is equal to 0.741 with the sig of $0.009<0.05$. This shows that the correlation between the two average level of knowledge before and after the illumination is strong and significant.

TABLE 4: PAIRED SAMPLES TEST KNOWLEDGE OF THE COMMUNITY BEFORE AND AFTER COUNSELING SANITATION WITH AUDIO-VISUAL MEDIA

\begin{tabular}{|c|c|c|c|c|c|c|c|c|}
\hline & \multicolumn{5}{|c|}{ Paired Differences } & \multirow{3}{*}{$t$} & \multirow{3}{*}{$D f$} & \multirow{3}{*}{$\begin{array}{c}\text { Sig. } \\
(2-t a i l e d)\end{array}$} \\
\hline & \multirow[t]{2}{*}{ Mean } & \multirow[t]{2}{*}{$\begin{array}{c}\text { Std. } \\
\text { Deviation }\end{array}$} & \multirow[t]{2}{*}{$\begin{array}{l}\text { Std. } \\
\text { Error } \\
\text { Mean }\end{array}$} & \multicolumn{2}{|c|}{$\begin{array}{l}\text { 95\% Confidence } \\
\text { Interval of the } \\
\text { Difference }\end{array}$} & & & \\
\hline & & & & Lower & Upper & & & \\
\hline Pair 1 Before-After & 1.04000 & 1.51327 & .30265 & 1.66465 & .41535 & 3.436 & 24 & .002 \\
\hline
\end{tabular}

Source: Data Processing, 2015

$\mathrm{T}_{\text {count }}$ value is equal to $3,436>\mathrm{t}_{\text {table }}$ value of $(0: 05 ; 24)$ was 1,711 with sig $0.002<0.05$. Because $\mathrm{t}{ }_{\text {count }}>\mathrm{t}_{\text {table }}$ and sig $<0.05$ then it can be concluded that there are significant differences between the level of public knowledge before and after counseling sanitation by using audio-visual media.

Here are the results Paired t-test for knowledge of sanitation management knowledge before and after the intervention in the form of counseling related to the improvement of water quality by means of a simple water filtration media by using the image can be seen in the table below:

TABLE 5: PAIRED SAMPLES STATISTICS COMMUNITY KNOWLEDGE BEFORE AND AFTER COUNSELING SANITATION WITH MEDIA IMAGES

\begin{tabular}{llrrrr}
\hline & Mean & $N$ & Std. Deviation & Std. Error Mean \\
\hline Pair 1 & Before & 6.0000 & 25 & 1.08012 & .21602 \\
& After & 6.8400 & 25 & 1.14310 & .22862 \\
\hline
\end{tabular}

Source: Data Processing, 2015

The above table shows that the mean and std. deviation of knowledge on before and after counseling. Before the extension by using audio-visual media the mean level of knowledge of 25 samples obtained 6.0000 with std. deviation 1.08012. while after counseling by using audio-visual media number knowledge level mean is equal to 6.8400 with std. deviation 1.14310 . 
TABLE 6: PAIRED SAMPLES CORRELATIONS PUBLIC KNOWLEDGE BEFORE AND AFTER COUNSELING SANITATION WITH MEDIA IMAGES

\begin{tabular}{rrrrr}
\hline & $N$ & Correlation & Sig. \\
\hline Pair 1 & Before and After & 25 & .636 & .016 \\
\hline
\end{tabular}

Source: Data Processing, 2015

The test results showed that the correlation between the two variables is equal to 0.636 with the sig of $0.016<0.05$. This shows that the correlation between the two average level of knowledge before and after the illumination is strong and significant.

TABLE 7: SAMPLES TEST PAIRED PUBLIC KNOWLEDGE BEFORE AND AFTER COUNSELING SANITATION WITH MEDIA IMAGES

\begin{tabular}{|c|c|c|c|c|c|c|c|c|}
\hline & \multicolumn{5}{|c|}{ Paired Differences } & \multirow{3}{*}{$t$} & \multirow{3}{*}{$D f$} & \multirow{3}{*}{$\begin{array}{l}\text { Sig. (2- } \\
\text { tailed) }\end{array}$} \\
\hline & \multirow[t]{2}{*}{ Mean } & \multirow[t]{2}{*}{$\begin{array}{c}\text { Std. } \\
\text { Deviation }\end{array}$} & \multirow[t]{2}{*}{$\begin{array}{l}\text { Std. } \\
\text { Error } \\
\text { Mean }\end{array}$} & \multicolumn{2}{|c|}{$\begin{array}{l}\text { 95\% Confidence } \\
\text { Interval of the } \\
\text { Difference }\end{array}$} & & & \\
\hline & & & & Lower & Upper & & & \\
\hline Pair 1 Before-After & .84000 & 1.37477 & .27495 & 1.40748 & .27252 & 3.055 & 24 & .005 \\
\hline
\end{tabular}

Source: Data Processing, 2015

$\mathrm{T}_{\text {count }}$ value is equal to $3,055>\mathrm{t}_{\text {table }}$ value of $(0: 05 ; 24)$ was 1,711 with sig $0.005<0.05$. Because $\mathrm{t}_{\text {count }}>\mathrm{t}_{\text {table }}$ and sig $<0.05$ then it can be concluded that there are significant differences between the level of public knowledge before and after counseling sanitation by using media images.

\section{Conclusion}

From the analysis it can be seen the tendency of dominant level of public knowledge by extension higher using audio-visual media compared with the use of media images. This trend can be seen from the mean value of the extension to the audiovisual media obtained at 1.04000 is greater than the mean value obtained counseling with media images of 0.84000 then the value $\mathrm{t}_{\text {count }}>\mathrm{t}_{\text {table }}$ indicates significant differences. Knowledge in this case is everything that includes memories of things that never learned and stored in memory. This may include facts, concepts and socialize the environmental education.

Based on these results when paired with several theories Bloom in Mujiono (2006), there is a strong and significant correlation to that given to the public domain with the concept of indicators of knowledge that is the memorization of knowledge or understanding that has been known by the public. While the public response to counseling before and after the audio-visual media there is a significant difference this has been revealed by Notoatmodjo (2007) in the field of environmental health is indispensable knowledge about environmental sanitation 
in order to improve environmental health conditions of the community. In line with Azrul (1996) stated that efforts oversight of environmental health factors need verification by the fact that can be observed by the public so that the extension to the medium of film showed a justification that the muddy water mixed with a very simple can turn into clear and healthy. One proof of mental frontier Chiras (1992), that science and technology will solve environmental problems.

Research locations in District Tallo Makassar with wells do not meet the conditions of the terms of the health of the environment, both in terms of construction and sanitary conditions were so bad that has a high risk, due to the environmental pollution to water quality physical (turbid water), both of which comes from a family latrines, garbage and household waste water.
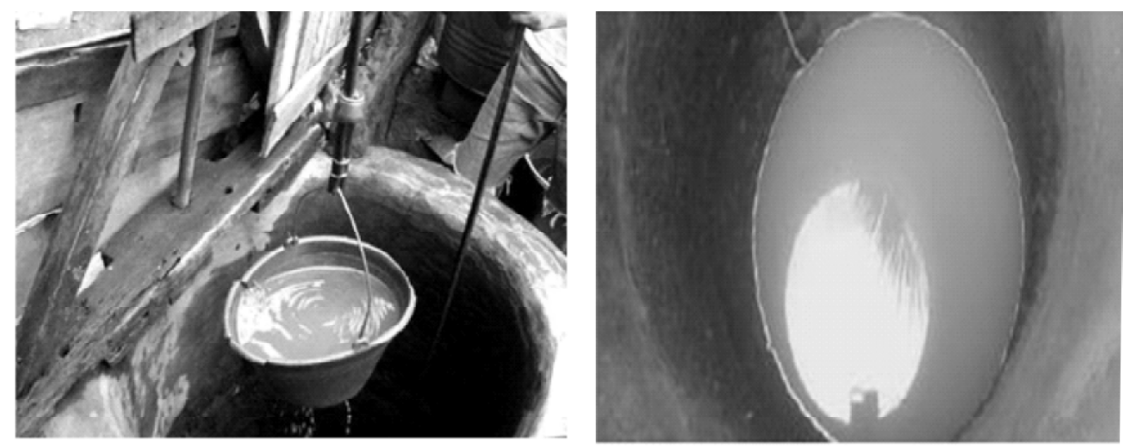

Figure 4: The quality of water wells that do not meet health requirements

\section{Conclusion}

From the research results can be seen the tendency of higher knowledge society with audio-visual media extension uses compared with using media images. This trend can be seen from the mean value of the extension to the audio-visual media obtained at 1.04000 is greater than the mean value obtained counseling with media images of 0.84000 then the value $\mathrm{t}_{{ }_{\text {count }}}>\mathrm{t}_{\text {table }}$ indicates significant differences.

\section{References}

Aswar, Azrul. (1996). Pengantar llmu Kesehatan Lingkungan. Jakarta: Mutiara Sumber Widya.

Chiras, Daniel D. (1992). Lessons from Nature: Learning to Live Sustainably on the Earth. Washington D.C: Island Press.

Mudjiono dalam Bloom Benyamin. (2006). Prinsip-Prinsip Belajar dan Asas Pembelajaran.

Notoatmodjo, Soekidjo. (2007). Promosi Kesehatan dan llmu Perilaku. Jakarta: Rineka Cipta.

Profil Dinas Kesehatan Kota Makassar. (2013). Kondisi sanitasi dan kesehatan lingkungan di Kecamatan Rappocini Kota Makassar.

Rauf, Bakhrani. (2000). Pembinaan Pengetahuan dan Sikap Lingkungan Masyarakat dalam Rangka Peningkatan Kualitas Lingkungan Makassar. Universitas Negeri Jakarta. 
Slamet, Juli Soemirat. (1994). Kesehatan Lingkungan. Yogyakarta: Gadjah Mada University Press.

Slamet, Juli Soemirat. (2004). Kesehatan Lingkungan. Yogyakarta: Gadjah Mada University Press.

Slamet, Juli Soemirat. (2011). Kesehatan Lingkungan. Yogyakarta: Gadjah Mada University Press.

Permenkes RI. No. 416 tahun (1990). Tentang Syarat-Syarat Kualitas Air Bersih. Jakarta. Kemenkes RI.

Undang-undang RI. No. 23 tahun (1992). Tentang Kesehatan. Jakarta: Kementerian Kesehatan RI.

Undang-undang RI. No. 32 tahun (2009). Tentang Pengelolaan Lingkungan Hidup. Jakarta: Kementerian Lingkungan Hidup.

Undang-undang RI. No. 36 tahun (2009). Tentang Upaya Kesehatan Lingkungan. Jakarta: Kemenkes RI.

WHO Unicef Joint Monitoring Program. (2004). Tentang MDG mid-assessment report Water R. Lym. Environmental health. 